\title{
Northern Iranian growth charts for children aged 7-11 years: compar- ison with international reference curves
}

Haleh Esmaili ${ }^{1}$, Mahmoud Hajiahmadi ${ }^{2}$, Maryam Fathi ${ }^{3}$ and Reza Ghadimi ${ }^{1}$

${ }^{1}$ Social Determinants of Health Research Center, Health Research Institute, Babol University of Medical Sciences, Babol, Mazandaran, Islamic Republic of Iran (Correspondence to: Reza Ghadimi: rezaghadimi@yahoo.com). ${ }^{2}$ Non-communicable Pediatric Disease Research Center, Health Research Institute, Babol University of Medical Sciences Babol, Mazandaran, Islamic Republic of Iran. ${ }^{3}$ Student Research Center, Babol University of Medical Sciences, Babol, Mazandaran, Islamic Republic of Iran.

\begin{abstract}
Background: Child body mass index (BMI) is an internationally accepted indicator to assess child health status. International BMI reference curves are available but their suitability for Iranian children in not known.

Aims: This study aimed to produce BMI-for-age growth curves for northern Iranian schoolchildren aged 7-11 years and compare them with the World Health Organization (WHO 2006) and Centers for Disease Control and Prevention (CDC 2000) reference curves.

Methods: Stratified multistage cluster sampling was used to select schoolchildren from urban and rural areas of Babol. Height and weight were measured and BMI calculated. Smoothed BMI-for-age growth curves were constructed for both sexes and compared with the WHO and CDC reference curves.

Results: A total of 4083 children aged 7-11 years were included; 48.8\% were boys and 56.7\% were urban residents The major significant differences between the Iranian curves in this study and the CDC2000 and WHO 2006 growth charts were in the upper centiles. The 5 th centile is close to the 5 th centiles of the reference curves.

Conclusions: BMI centiles for 7-11 years schoolchildren in Babol differed significantly from the international growth reference curves. Therefore, local and population-specific BMI curves should be developed to assess physical growth of children.

Keywords: Body mass index, Growth charts, Schoolchildren, World Health Organization, Centers for Disease Control and Prevention, Iran

Citation: Esmaili H; Hajiahmadi M; Fathi M; Ghadimi R. Northern Iranian growth charts for children aged 7-11 years: comparison with international reference curves. East Mediterr Health J. 2018;24(12):1146-1154. https://doi.org/10.26719/2018.24.12.1146

Received: 29/11/15; accepted: 16/07/17

Copyright (C) World Health Organization (WHO) 2018. Some rights reserved. This work is available under the CC BY-NC-SA 3.o IGO license (https:// creativecommons.org/licenses/by-nc-sa/3.o/igo).
\end{abstract}

\section{Introduction}

Anthropometric measurements including weight, height, waist circumference and body mass index (BMI) are simple and reliable indicators that provide useful information about physical growth, body composition, nutrition status and the risk of noncommunicable diseases $(1,2)$. Although BMI has some limitations, especially in growing children, it is an internationally accepted indicator and is used widely for screening and monitoring body fat $(3,4)$. Moreover, it is an important component of primary care in paediatrics and is a useful public health tool to assess child health status (5).

Two BMI reference curves-the World Health Organization (WHO 2006) and the Centers for Disease Control and Prevention (CDC 2000)-have been widely applied to calculate the anthropometric indicators of growth $(6,7)$. WHO (2006) was developed using children's data from 6 countries [Brazil, Ghana, India, Norway, Oman and United States of America (USA)], while CDC (2000) criteria are based on US children and adolescents aged 0-20 years. Some studies in different countries have found differences between their own child growth charts and these 2 international reference curves (8-10). Therefore, for BMI to be applicable in practice in the paediatric age group, standards should better be defined by age and gender based on local data $(11,12)$. Now, many countries have their own BMI curves according to their child population; however, limited national data exist for Asian children, notably from children in Middle Eastern countries (12-16).

This study aimed to produce BMI-for-age curves for northern Iranian children aged 7-11 years and compare them with the WHO and CDC reference curves.

\section{Methods}

\section{Study setting}

Mazandaran province is located in the north of the Islamic Republic of Iran between the Caspian Sea and Alborz mountains. It consists of 15 counties. The total population of the province in 2011 was estimated to be 3.074 million. Babol county is the biggest county of Mazandaran and is located in the middle of the province. Babol city is the third largest city in the north of the Islamic Republic of Iran. At the 2012 census, the population of Babol county was 495 472, in 149363 families.

\section{Study design and population}

This was a cross-sectional survey conducted in 2012. A 
stratified multistage cluster sampling method was used to select children from urban and rural areas of Babol. All primary schools were stratified into urban/rural, and then into girls'/boys' schools. Then 5 rural and 6 urban girls' schools and 5 rural and 6 urban boys' schools were randomly selected. In each selected school, all students in 5 age groups (ages 7-11 years) were listed and 20 children were randomly selected for each age group in each school. The sample size was calculated to be about 200 children in each urban/rural area from both sexes and different age groups (7-11 years). From 4400 schoolchildren recruited in the study, 317 were excluded because of incomplete data. Therefore, 4083 children were included in the final analysis (1 993 boys and 2090 girls) from urban and rural areas of Babol. The detailed sampling methodology has been described previously (17) and is shown in Figure 1. Students with a history of any chronic disease or disability and those taking medication or on special diets (based on their school health records) were excluded from the study before collecting data.

\section{Anthropometric measurements}

All anthropometric indices were measured by a trained research team. Weight was measured in the morning before eating breakfast (students were asked to come to school without eating breakfast) and in light clothing us-

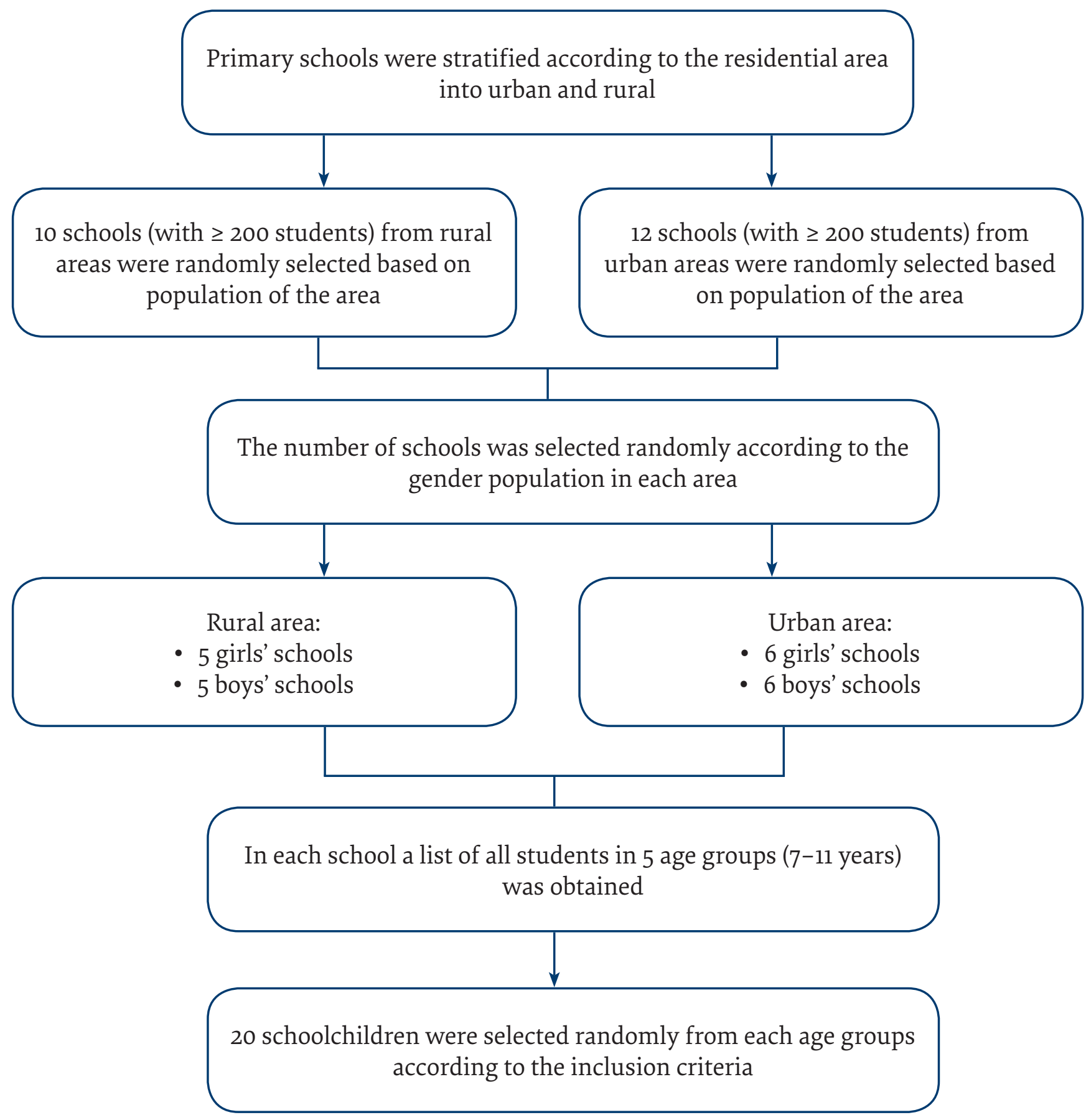


ing an Omron digital scale (model BF-511) with a precision of $0.1 \mathrm{~kg}$. A Seca stadiometer (precision of $0.1 \mathrm{~cm}$ ) was used to measure height, standing erect without shoes. BMI was calculated as weight $(\mathrm{kg}) /[\text { height }(\mathrm{m})]^{2}$.

\section{Statistical analysis}

All data were analysed using SPSS, version 21. The Kolmogorov-Smirnov test was used to determine normal distribution $(P=0.8)$. Data were analysed using descriptive statistics to report general characteristics of the schoolchildren, and the independent sample t-test was used to assess mean differences between the sexes. One way ANOVA was used to examine the differences between BMI and age. A P-value $<0.05$ was considered statistically significant.

The Box-Cox power transformation was used to transform data to select the best model. To develop agerelated centiles for both sexes and to smooth and fit the curves, the Cole LMS method with the maximum penalized likelihood was used, where $\mathrm{L}=$ skewness, $\mathrm{M}=$ median and $\mathrm{S}=$ coefficient of variation. LMSchartmaker Pro, version 2.3 software, was provided by the Medical Research Council, United Kingdom and used according to the method proposed by Cole and colleagues (18).The chi-squared test was used to determine normality and goodness of fit.

\section{Ethical considerations}

The study protocol was approved by the Ethics Committee of Babol University of Medical Sciences, Babol, Islamic Republic of Iran.

The children's agreement to participate and the written informed consent of the parents were obtained before enrolment.

\section{Results}

The participants in this cross-sectional study were 4083 students, aged 7 to 11 years (1 993 boys and 2090 girls) from urban and rural areas of Babol, Mazandaran Province, Northern Islamic republic of Iran.

The mean (SD) age of the students was 9.46 (1.27) years. The sample consisted of $48.8 \%$ boys and $51.2 \%$ girls: $56.7 \%$ were from urban and $43.3 \%$ from rural residences. Mean (SD) for weight, height and BMI were $32.91(10.12) \mathrm{kg}$, $133.76(9.73) \mathrm{cm}$ and $18.08(3.68) \mathrm{kg} / \mathrm{m}^{2}$ respectively. Table 1 shows the mean (SD) anthropometric measures by sex and age. All differences between the ages were statistically significant $(P<0.05)$, whereas no statistically significant difference was found between anthropometric measures and sex $(P=0.09)$.

The BMI centile values in primary-school children are shown in Table 2. The mean BMI 50th centile in boys increased gradually from 7 to 9 years $(15.80-16.82 \mathrm{~kg} /$ $\mathrm{m}^{2}$ ) and then increased substantially. A different pattern was seen in girls, with a gradual and constant increase in BMI from 7 to 9 years $\left(15.68-17.50 \mathrm{~kg} / \mathrm{m}^{2}\right)$ and a very slight increase from 9 to 10 years $\left(17.50-17.72 \mathrm{~kg} / \mathrm{m}^{2}\right)$ and a notable increase from 10 to 11 years $\left(17.72-19.21 \mathrm{~kg} / \mathrm{m}^{2}\right)$.

The mean differences in BMI centiles between our data and the WHO and CDC reference values for both girls and boys are shown in Table 3. BMI centiles in our northern Iranian population were slightly greater than in the 2 reference populations, except for the 85th and 95th centiles where the differences were greater.

Smoothed BMI curves for boys and girls were constructed. Figure 2 shows the 5th, 10th, 25th, 50th, 75th and 95th smooth centiles for both boys and girls. In both boys and girls, BMI centiles increased with age but with

\begin{tabular}{llll}
\hline $\begin{array}{l}\text { Table } 1 \text { Anthropometric measurements of the Iranian schoolchildren, by age and sex } \\
\text { Age (years) }\end{array}$ & $\begin{array}{c}\text { Weight (kg) } \\
\text { Mean (SD) }\end{array}$ & $\begin{array}{c}\text { Height (cm) } \\
\text { Mean (SD) }\end{array}$ & $\begin{array}{c}\text { BMI (kg/m } \mathbf{m}^{2} \\
\text { Mean (SD) }\end{array}$ \\
\hline Boys & & & \\
7 & $25.09(5.53)$ & $122.96(5.18)$ & $16.50(2.81)$ \\
8 & $29.10(7.01)$ & $129.50(5.84)$ & $17.19(3.05)$ \\
9 & $32.82(8.17)$ & $134.70(6.16)$ & $17.93(3.44)$ \\
10 & $36.24(9.52)$ & $139.14(5.84)$ & $18.70(3.84)$ \\
11 & $41.62(11.92)$ & $143.13(8.29)$ & $20.22(4.36)$ \\
Girls & & & \\
7 & $24.56(5.30)$ & $121.99(5.74)$ & $16.39(2.62)$ \\
8 & $28.93(7.09)$ & $127.43(6.05)$ & $17.65(3.34)$ \\
9 & $33.11(8.18)$ & $133.84(6.45)$ & $18.32(3.49)$ \\
10 & $36.43(9.32)$ & $139.67(7.50)$ & $18.47(3.48)$ \\
11 & $43.80(11.97)$ & $146.79(8.37)$ & $20.14(4.43)$ \\
\hline
\end{tabular}

Independent sample t-test; $P<0.05$ was considered statistically significant.

$B M I=$ body mass index,$S D=$ standard deviation . 


\begin{tabular}{|c|c|c|c|c|c|c|c|c|c|c|c|c|}
\hline \multirow[t]{2}{*}{ Age (years) } & \multirow[b]{2}{*}{$\mathbf{L}$} & \multirow[b]{2}{*}{$\mathbf{M}$} & \multirow[b]{2}{*}{$\mathbf{s}$} & \multirow[b]{2}{*}{5 th } & \multirow[b]{2}{*}{ 10th } & \multicolumn{4}{|c|}{ Body mass index $\left(\mathrm{kg} / \mathrm{m}^{2}\right)$} & \multirow[b]{2}{*}{ 85th } & \multirow[b]{2}{*}{ 9oth } & \multirow[b]{2}{*}{$95^{\text {th }}$} \\
\hline & & & & & & 15th & 25th & 50th & 75th & & & \\
\hline \multicolumn{13}{|l|}{ Boys } \\
\hline 7 & -2.60 & 15.90 & 0.12 & 13.48 & 14.03 & 14.36 & 14.90 & 15.80 & 17.23 & 18.37 & 19.85 & 23.27 \\
\hline 8 & -2.30 & 16.49 & 0.13 & 13.81 & 14.29 & 14.59 & 14.98 & 16.19 & 18.58 & 20.17 & 21.63 & 23.72 \\
\hline 9 & -1.95 & 17.13 & 0.15 & 13.97 & 14.59 & 14.92 & 15.50 & 16.82 & 19.84 & 21.57 & 22.99 & 24.79 \\
\hline 10 & -1.52 & 18.05 & 0.17 & 14.27 & 14.92 & 15.28 & 15.88 & 17.74 & 20.62 & 23.22 & 24.57 & 26.55 \\
\hline 11 & -1.09 & 19.22 & 0.20 & 14.58 & 15.03 & 15.60 & 16.60 & 19.01 & 22.74 & 24.89 & 27.94 & 30.24 \\
\hline \multicolumn{13}{|l|}{ Girls } \\
\hline 7 & -1.99 & 15.90 & 0.13 & 13.94 & 13.80 & 14.09 & 14.53 & 15.68 & 17.58 & 19.00 & 20.44 & 22.11 \\
\hline 8 & -1.78 & 16.85 & 0.15 & 14.00 & 14.34 & 14.61 & 15.21 & 16.68 & 19.41 & 21.21 & 22.61 & 24.35 \\
\hline 9 & -1.20 & 15.67 & 0.18 & 14.13 & 14.65 & 14.98 & 15.50 & 17.50 & 20.60 & 22.16 & 23.55 & 25.15 \\
\hline 10 & -1.20 & 15.67 & 0.18 & 14.26 & 14.81 & 15.24 & 15.82 & 17.72 & 20.37 & 22.32 & 23.50 & 25.50 \\
\hline 11 & -0.73 & 19.37 & 0.19 & 14.42 & 15.26 & 15.67 & 16.54 & 19.21 & 22.71 & 25.05 & 26.82 & 28.99 \\
\hline
\end{tabular}

$L=$ skewness, $M=$ median, $S=$ coefficient of variation.

\begin{tabular}{|c|c|c|c|c|c|c|c|c|c|c|}
\hline \multirow[t]{3}{*}{ References } & \multicolumn{10}{|c|}{ Body mass index centiles $\left(\mathrm{kg} / \mathrm{m}^{2}\right)$} \\
\hline & \multicolumn{5}{|c|}{ Boys } & \multicolumn{5}{|c|}{ Girls } \\
\hline & 5th & 15th & 50th & 85th & 95th & 5th & 15th & 5oth & 85th & 95th \\
\hline US CDC 2000 & -0.98 & - & -0.86 & -2.93 & -4.58 & -0.3 & - & -0.98 & -2.7 & -3.37 \\
\hline WHO 2006 & -0.84 & -0.03 & -0.61 & -3.02 & -5.43 & -0.21 & -0.09 & -0.65 & -2.7 & -4.02 \\
\hline
\end{tabular}

US CDC = United States Centers for Disease Control and Prevention, $\mathrm{WHO}=$ World Health Organization.
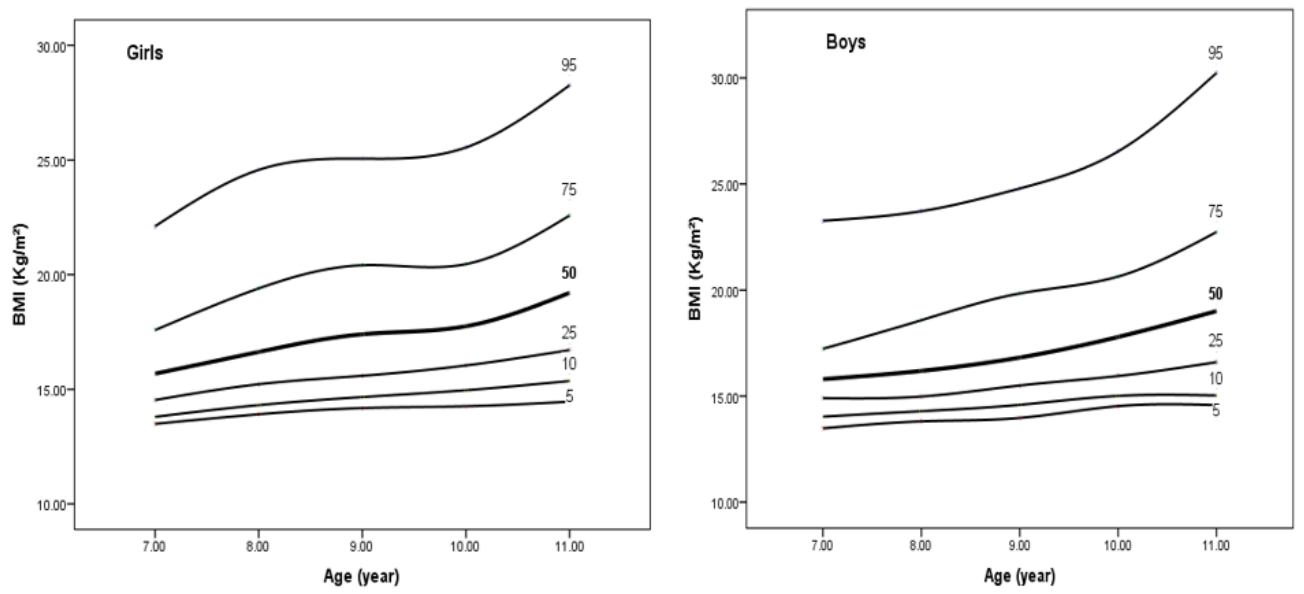

Figure 2 Smoothed age- and gender-specific body mass index centile curves for northern Iranian children aged 7-11 years

different patterns. The 5 th and 5oth centile curves had a slight increase, while in both sexes a sharp increase was seen from 10 to 11 years in the higher centiles.

The BMI centile curves (5th, 50th, 85th and 95th) of our schoolchildren compared with the CDC and WHO centiles are shown in Figures 2 and 3. The 5th centile of
BMI for boys was very similar to the WHO 5 th centile with a marginal increase after age 10 years. In girls up to age 10 years, the WHO 5th centile curve was slightly lower than Iranian girls, while it closely matched the WHO curve between 10 and 11 years. The 5th centile for Iranian boys was close to the 5 th percentile of the CDC 

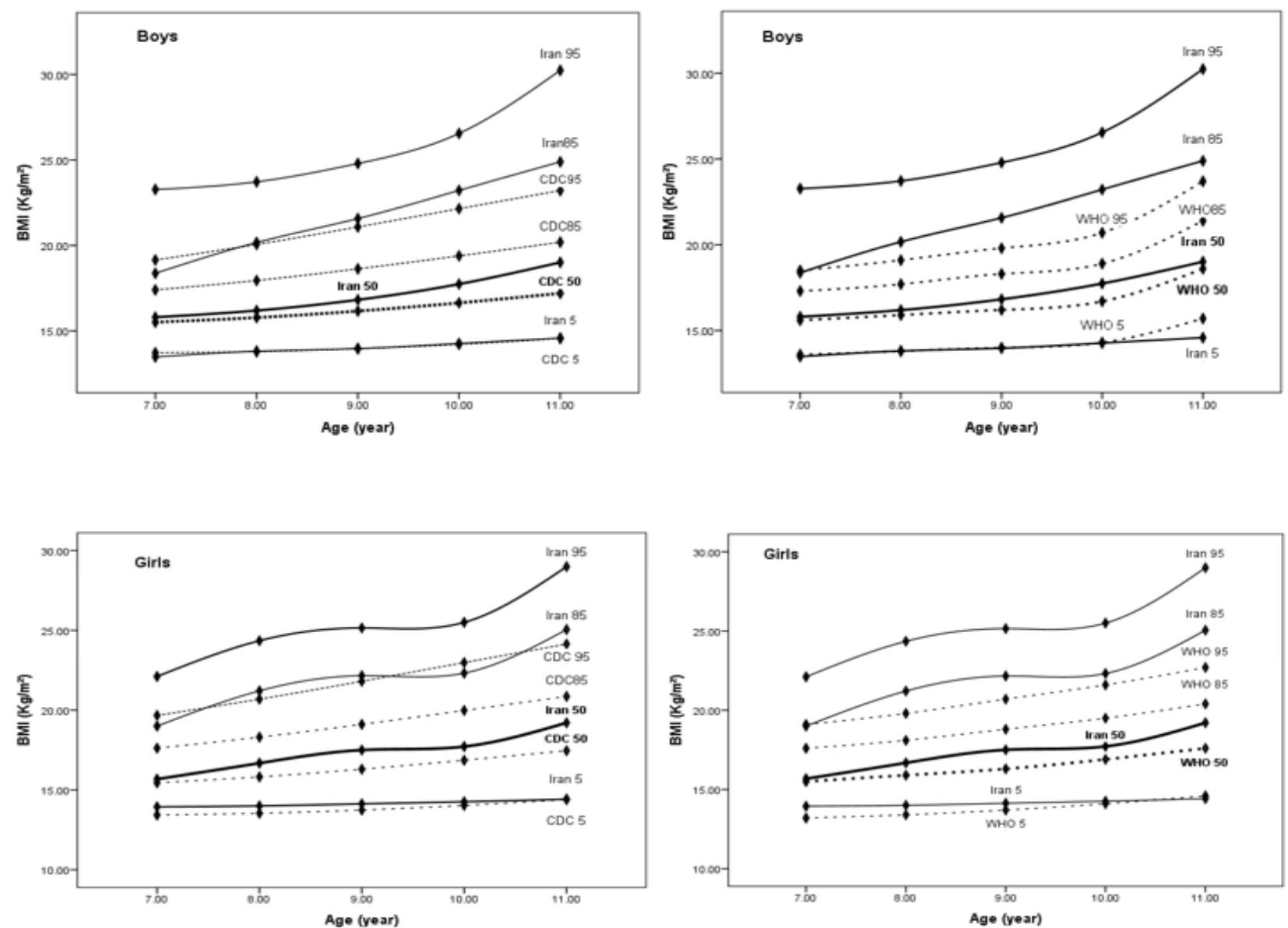

Figure 3 Age- and gender-specific body mass index centile curves for northern Iranian children aged 7-11 years and the World Health Organization (WHO) and Centers for Disease Control and Prevention (CDC) reference populations (WHO 2006 and CDC 2000)

curve, while it was higher in Iranian girls.

Figure 4 compares the 85th and 95th centiles of the WHO and CDC curves with the 75 th, 85th and 95th centile curves for Iranian children. The 85th and 95th centiles for Iranian children were much higher than in the WHO and CDC curves, especially after age 8 years. Furthermore, in girls, the 75th BMI centile was higher than the 85th centile in the CDC and WHO reference curves. It was close to the 95th centile of the WHO curve but lower than the CDC 95th centile. A similar pattern was found in boys. The 85th centile curve for Iranian children (both boys and girls) was very similar to the 95th centile of CDC (and increased almost identically) while it was higher than the 95th percentile of the WHO curve.

\section{Discussion}

Standardized BMI curves offer an opportunity to monitor and screen children's physical growth $(4,6)$. WHO and CDC standards are used worldwide because of the absence of local data and Iranian children are no exception (19-21).

We found differences between northern Iranian regional growth curves and the WHO and CDC references curves, especially in the upper BMI-for-age curves. Some studies have demonstrated the similarity in growth trends of pre-pubertal children and they believe significance differences appear in pubertal and post-pubertal stages, but the OLAF study in Poland showed some differences even in pre-pubertal children $(22,23)$. Although, our study did not assess pubertal stages, our growth curves show various difference compared with the reference curves for 7-11-year-olds in the upper centiles. These differences may be a result of genetic, demographic and nutritional factors. In the current study, the 5th centiles of northern Iranian children overlapped with the WHO and CDC values with only slight differences. This indicates the growth trends are similar for both Iranian children and the 2 reference populations.

However, for Iranian children, the 85th and 95th BMI centiles were considerably higher than the WHO and CDC reference curves in ages 7-11 years. Generally, the 85th and 95th BMI centiles are used to define overweight and obesity respectively (11). Therefore, our study suggests that for Iranian children, the 75th -85 th and $\geq 85$ th centiles in the CDC and WHO references should be considered as overweight and obesity respectively. In contrast, national growth curves for Pakistani children were significantly lower than the WHO and CDC references in the upper centiles (24). Other studies in different regions and 

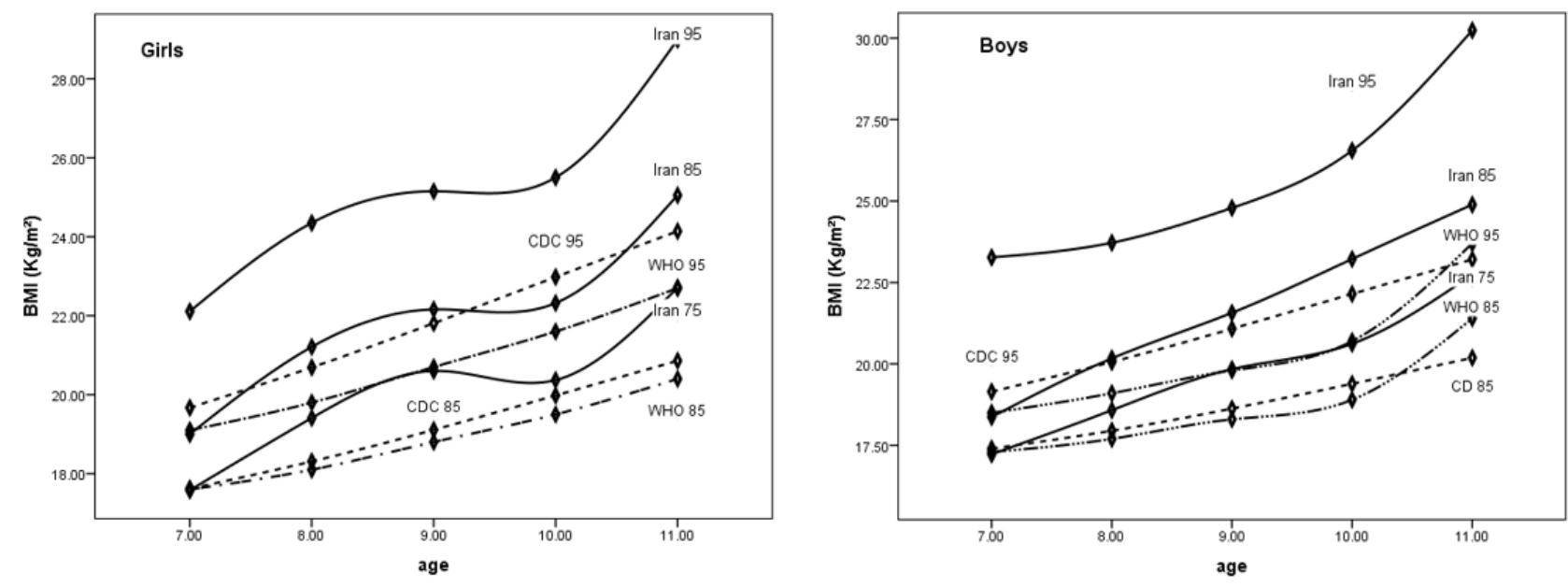

Figure 4 Upper centile (75th, 85th and 95th) curves for northern Iranian children aged 7-11 years and the World Health Organization (WHO) and Centers for Disease Control and Prevention (CDC) reference populations (WHO 2006 and CDC 2000)

countries have reported significant differences between their national growth curves for children and the WHO and CDC reference curves $(25-27)$.

These findings reflect imprecision of the WHO and CDC reference curves in estimating physical growth for all populations. However, the influence of external conditions on growth might explain the difference to some degree. In addition, because of differences in genetic, pubertal stage, race and environmental and demographic factors in different parts of the Islamic Republic of Iran, the use of these standard curves can be imprecise and misleading $(28,29)$.

Several reasons can explain the shift in BMI in northern Iranian schoolchildren. Urbanization, nutrition transition and consumption of fats and sugar-rich foods, technological transformation (using motorized transport instead of walking, watching television/ using the computer instead of playing), and low levels of physical activity are factors contributing to the rise in BMI $(30,31)$. Therefore, the need for national BMI centile reference curves for children and adolescents has been increasingly recognized by countries in order to identify overweight and obesity $(7,29)$. To the best of our knowledge, this study is the first to provide BMI centile curves for schoolchildren in northern Islamic Republic of Iran using a large sample and to compare them with international references.

The main limitations of this study were the fact that the BMI centile curves obtained were based on crosssectional data not longitudinal data and that pubertal status was not considered and examined in children, especially in girls.

In conclusion, data gathered from 4083 , children aged 7 to 11 years from Babol (northern Islamic Republic of Iran) were used to develop BMI centile curves by age and sex. The study provides baseline data for time trend analysis and for comparisons with international data. The differences in these centiles between the CDC 2000 and WHO 2006 references were significant. Therefore, for BMI to be useful in practice, standards should better be defined and based on local data. Our findings cannot be generalized to other areas of the Islamic Republic of Iran because of differences between regions of the country (32). Therefore, further studies are needed to develop more accurate and appropriate BMI reference curves for evaluation of physical growth, and the magnitude of underweight, overweight and obesity in children in the Islamic Republic of Iran and the Middle East region.

\section{Acknowledgements}

We would like to thank all of the staff, students and parents of the participating schools for their cooperation, collaboration and support.

Funding: This study was supported by the vice chancellery for research of the Babol University of Medical Sciences (grant no: 674).

Competing interests: None declared. 


\section{Comparaison des courbes de croissance d'enfants de 7 à 11 ans du nord de la République islamique d'Iran avec les courbes de référence internationales \\ Résumé}

Contexte : L'indice de masse corporelle (IMC) des enfants est un indicateur reconnu internationalement pour évaluer l'état de santé des enfants. Des courbes d'IMC de référence internationales sont disponibles, mais leur adéquation à la réalité des enfants iraniens est encore méconnue.

Objectifs : La présente étude visait à produire des courbes de croissance représentant l'IMC-pour-l'âge d'écoliers de 7 à 11 ans du nord de la République islamique d'Iran et à les comparer avec les courbes de référence de l'OMS (2006) et des Centers for Disease Control and Prevention (2000).

Méthodes : Un échantillonnage stratifié en grappe à plusieurs niveaux a été utilisé pour sélectionner des écoliers dans des zones rurales et urbaines de Babol. La taille et le poids ont été mesurés et l'IMC a été calculé. Des courbes de croissance lisses de croissance montrant l'IMC-pour-l'âge ont été créées pour les deux sexes et comparées avec les courbes de référence de l'OMS et des CDC.

Résultats : Au total, 4083 enfants de 7 à 11 ans ont été inclus dans l'étude : 48,8\% étaient des garçons et 56,7\% résidaient en zones urbaines. Les différences majeures observées entre les courbes iraniennes produites dans le cadre de cette étude et les courbes de croissance des CDC (2000) et de l'OMS (2006) concernaient les centiles supérieurs. Le cinquième centile des courbes iraniennes était proche du cinquième centile des courbes de référence.

Conclusions : Les courbes des centiles d'IMC des écoliers de 7 à 11 ans de Babol différaient significativement des courbes de croissance de référence internationales. Des courbes d'IMC propres à la population et au lieu devraient donc être créées pour évaluer la croissance physique des enfants.

$$
\text { هالة إسماعيل، محمود حاجي احمدي، مريم فتحي، رضا للأطفال الذين تتراوح أعمارهم ما بين V-V } 11 \text { سنة بشمال إيران: مقارنة مع المنحنيات المرجعية الدولية }
$$

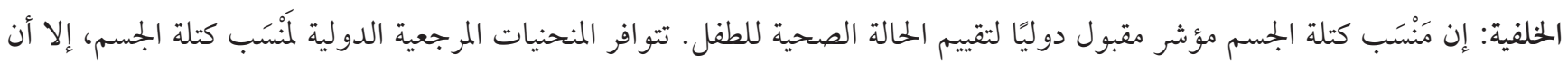

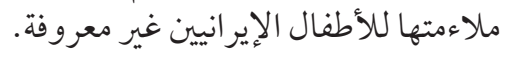

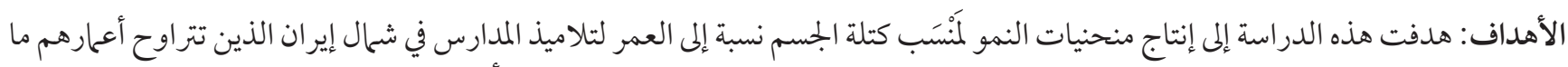

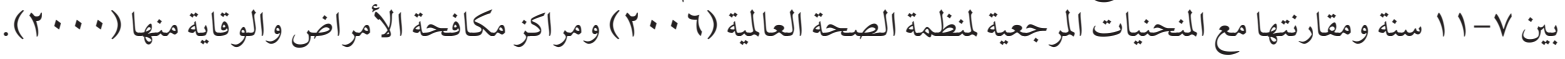

طرق البحث: تم أخذ العينات الطبقية العنقودية المتعددة المراحل لاختئيار تلاميذ المدارس من المناطق الحضرية والريفية في بابول. تم قياس الطول

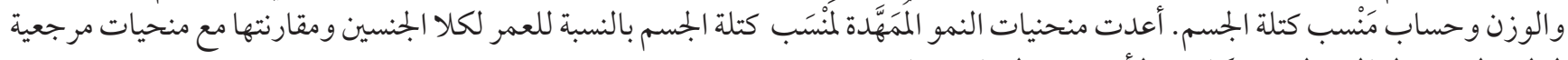

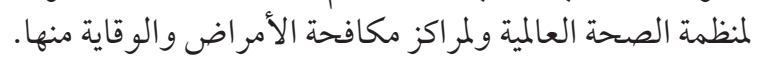

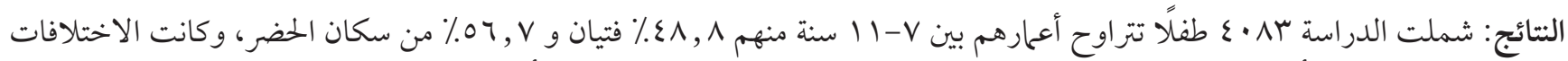

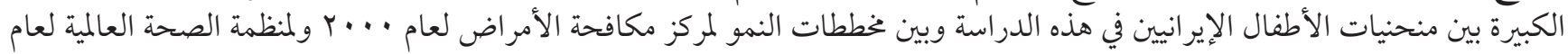

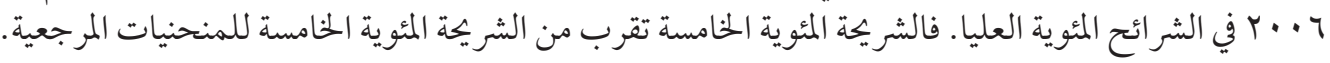

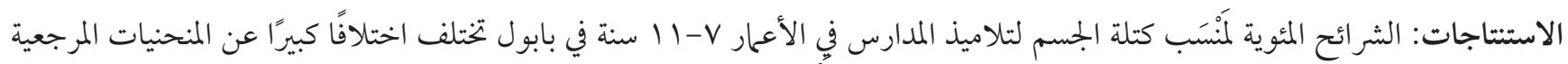

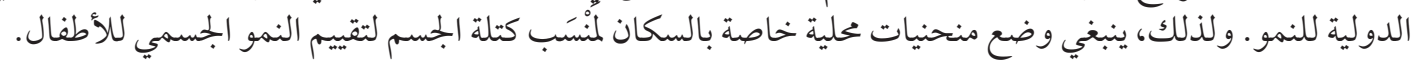

\section{References}

1. Freedman DS, Katzmarzyk PT, Dietz WH, Srinivasan SR, Berenson GS. Relation of body mass index and skinfold thicknesses to cardiovascular disease risk factors in children: the Bogalusa Heart Study. Am J Clin Nutr. 2009 Jul;90(1):210-6. https://doi. org/10.3945/ajcn.2009.27525 PMID:19420092

2. Andaki ACR, Tinôco ALA, Mendes EL, Andaki Júnior R, Hills AP, Amorim PRS. Anthropometry and physical activity level in the prediction of metabolic syndrome in children. Public Health Nutr. 2014 Oct;17(10):2287-94. https://doi.org/10.1017/ S136898001300253X PMID:24063585

3. Cole TJ, Lobstein T. Extended international (IOTF) body mass index cut-offs for thinness, overweight and obesity. Pediatr Obes. 2012 Aug;7(4):284-94. https://doi.org/10.1111/j.2047-6310.2012.00064.x PMID:22715120

4. $\quad$ Nagy P, Kovacs E, Moreno LA, Veidebaum T, Tornaritis M, Kourides Y, et al.; IDEFICS consortium. Percentile reference values for anthropometric body composition indices in European children from the IDEFICS study. Int J Obes. 2014 Sep;38(S2) Suppl 2:S15-25. https://doi.org/10.1038/ijo.2014.131 PMID:25219408 
5. Victora CG, Adair L, Fall C, Hallal PC, Martorell R, Richter L, et al.; Maternal and Child Undernutrition Study Group. Maternal and child undernutrition: consequences for adult health and human capital. Lancet. 2008 Jan 26;371(9609):340-57. https://doi. org/10.1016/So140-6736(07)61692-4 PMID:18206223

6. Kuczmarski RJ, Ogden CL, Guo SS, Grummer-Strawn LM, Flegal KM, Mei Z, et al. 2000 CDC growth charts for the United States: methods and development. Vital Health Stat 11. 2002 May;(246):1-190. PMID:12043359.

7. de Onis M, Onyango AW, Borghi E, Siyam A, Nishida C, Siekmann J. Development of a WHO growth reference for school-aged children and adolescents. Bull World Health Organ. 2007 Sep;85(9):660-7. https://doi.org/10.2471/BLT.07.043497 PMID:18026621

8. Pedrosa C, Correia F, Seabra D, Oliveira BM, Simões-Pereira C, Vaz-de-Almeida MD. Prevalence of overweight and obesity among 7-9-year-old children in Aveiro, Portugal: comparison between IOTF and CDC references. Public Health Nutr. 2011 Jan;14(1):14-9. https://doi.org/10.1017/S1368980009991789 PMID:19825211

9. Twells LK, Newhook LA. Obesity prevalence estimates in a Canadian regional population of preschool children using variant growth references. BMC Pediatr. 201102 28;11(1):21. https://doi.org/10.1186/1471-2431-11-21 PMID:21356057

10. Pelegrini A, Silva DA, Gaya AC, Petroski EL. Comparison of three criteria for overweight and obesity classification in Brazilian adolescents. Nutr J. 2013 Jan 7;12:5. https://doi.org/10.1186/1475-2891-12-5 PMID:23294869

11. Centers for Disease Control and Prevention. National Center for Health Statistics. CDC Growth Charts: United States: (http:// www.cdc.gov/growthcharts/background.htm, accessed August 2009).

12. Mansourian M, Marateb HR, Kelishadi R, Motlagh ME, Aminaee T, Taslimi M, et al. First growth curves based on the World Health Organization reference in a nationally-representative sample of pediatric population in the Middle East and North Africa (MENA): the CASPIAN-III study. BMC Pediatr. 201209 17;12(1):149. https://doi.org/10.1186/1471-2431-12-149 PMID:22985219

13. Ozturk A, Mazicioglu MM, Hatipoglu N, Budak N, Keskin G, Yazlak Z, et al. Reference body mass index curves for Turkish children 6 to 18 years of age. J Pediatr Endocrinol Metab. 2008 Sep;21(9):827-36. https://doi.org/10.1515/JPEM.2008.21.9.827 PMID:18924576

14. Roelants M, Hauspie R, Hoppenbrouwers K. References for growth and pubertal development from birth to 21 years in Flanders, Belgium. Ann Hum Biol. 2009 Nov-Dec;36(6):680-94. https://doi.org/10.3109/03014460903049074 PMID:19919503

15. Khadilkar V, Khadilkar A, Cole T, Sayyad M. Cross-sectional growth curves for height, weight and body mass index for affluent Indian children, 2007. Indian Pediatr. 2009 Jun;46(6):477-89. PMID:19556658

16. Saari A, Sankilampi U, Hannila M-L, Kiviniemi V, Kesseli K, Dunkel L. New Finnish growth references for children and adolescents aged o to 20 years: Length/height-for-age, weight-for-length/height, and body mass index-for-age. Ann Med. 2011 May;43(3):235-48. https://doi.org/10.3109/07853890.2010.515603 PMID:20854213

17. Ghadimi R, Asgharzadeh E, Sajjadi P. Obesity among elementary schoolchildren: A growing concern in the North of Iran, 2012. Int J Prev Med. 201510 12;6(1):99. PMID:26605020

18. Cole TJ, Freeman JV, Preece MA. Body mass index reference curves for the UK, 1990. Arch Dis Child. 1995 Jul;73(1):25-9. https:// doi.org/10.1136/adc.73.1.25 PMID:7639544

19. Grummer-Strawn LM, Reinold C, Krebs NF; Use of World Health Organization and CDC growth charts for children aged 0-59 months in the United States. MMWR Recomm Rep. 2010 Sep 10;59(RR-9):1-15 PMID:20829749.

20. de Onis M, Onyango A, Borghi E, Siyam A, Blössner M, Lutter C; WHO Multicentre Growth Reference Study Group. Worldwide implementation of the WHO child growth standards. Public Health Nutr. 2012 Sep;15(9):1603-10. https://doi.org/10.1017/ S136898001200105X PMID:22717390

21. Mirmiran P, Sherafat Kazemzadeh R, Jalali Farahani S, Azizi F. Childhood Obesity in the Middle East: a review. East Mediterr Health J. 2010 Sep;16(9):1009-17. PMID: 21218730.

22. Kulaga Z, Litwin M, Tkaczyk M, Rózdzyńska A, Barwicka K, Grajda A, et al. The height-, weight-, and BMI-for-age of Polish school-aged children and adolescents relative to international and local growth references. BMC Public Health. 201003 4;10(1):109. https://doi.org/10.1186/1471-2458-10-109 PMID:20199693

23. Haas JD, Campirano F. Interpopulation variation in height among children 7 to 18 years of age. Food Nutr Bull. 2006 Dec;27(4) Suppl Growth Standard:S212-23. https://doi.org/10.1177/15648265060274S505 PMID:17361658

24. Mushtaq MU, Gull S, Mushtaq K, Abdullah HM, Khurshid U, Shahid U, et al. Height, weight and BMI percentiles and nutritional status relative to the international growth references among Pakistani school-aged children. BMC Pediatr. 2012 03 19;12(1):31. https://doi.org/10.1186/1471-2431-12-31 PMID:22429910

25. Ma J, Wang Z, Song Y, Hu P, Zhang B. BMI percentile curves for Chinese children aged 7-18 years, in comparison with the WHO and the US Centers for Disease Control and Prevention references. Public Health Nutr. 2010 Dec;13(12):1990-6. https://doi. org/10.1017/S1368980010000492 PMID:20359376

26. Guedes DP, De Matos JAB, Lopes VP, Ferreirinha JE, Silva AJ. Physical growth of schoolchildren from the Jequitinhonha Valley, Minas Gerais, Brazil: Comparison with the CDC-2000 reference using the LMS method. Ann Hum Biol. 2010 Aug;37(4):574-84 https://doi.org/10.3109/03014460903524469 PMID:20113180

27. Al Herbish AS, El Mouzan MI, Al Salloum AA, Al Qureshi MM, Al Omar AA, Foster PJ, et al. Body mass index in Saudi Arabian children and adolescents: a national reference and comparison with international standards. Ann Saudi Med. 2009 SepOct;29(5):342-7. https://doi.org/10.4103/0256-4947.55162 PMID:19700890 
28. Butte NE, Garza C, de Onis M. Evaluation of the feasibility of international growth standards for school-aged children and adolescents. Food Nutr Bull. 2006 Dec;27(4) Suppl Growth Standard:S169-74. https://doi.org/10.1177/15648265060274S501 PMID:17361654

29. Bundak R, Furman A, Gunoz H, Darendeliler F, Bas F, Neyzi O. Body mass index references for Turkish children. Acta Paediatr. 2006 Feb;95(2):194-8. https://doi.org/10.1080/08035250500334738 PMID:16449026

30. The world health report 2002: reducing risks, promoting healthy life. Geneva: World Health Organization; 2002.

31. Rashidi A, Mohammadpour-Ahranjani B, Vafa MR, Karandish M. Prevalence of obesity in Iran. Obes Rev. 2005 Aug;6(3):191-2. https://doi.org/10.1111/j.1467-789X.2005.00174.x PMID:16045632

32. Esmaeil Motlagh M, Nasrollahpour Shirvani SD, Ghadimi R, Taheri M, Hassanzadeh-Rostami Z. Optimal anthropometric cut-off points to predict overweight and obesity: a cross-sectional survey in Iranian females. Iran Red Crescent Med J. 2017;19(5):e41497. https://doi.org/10.5812/ircmj.41497 